\title{
A relevância da Química para 0 cidadão
}
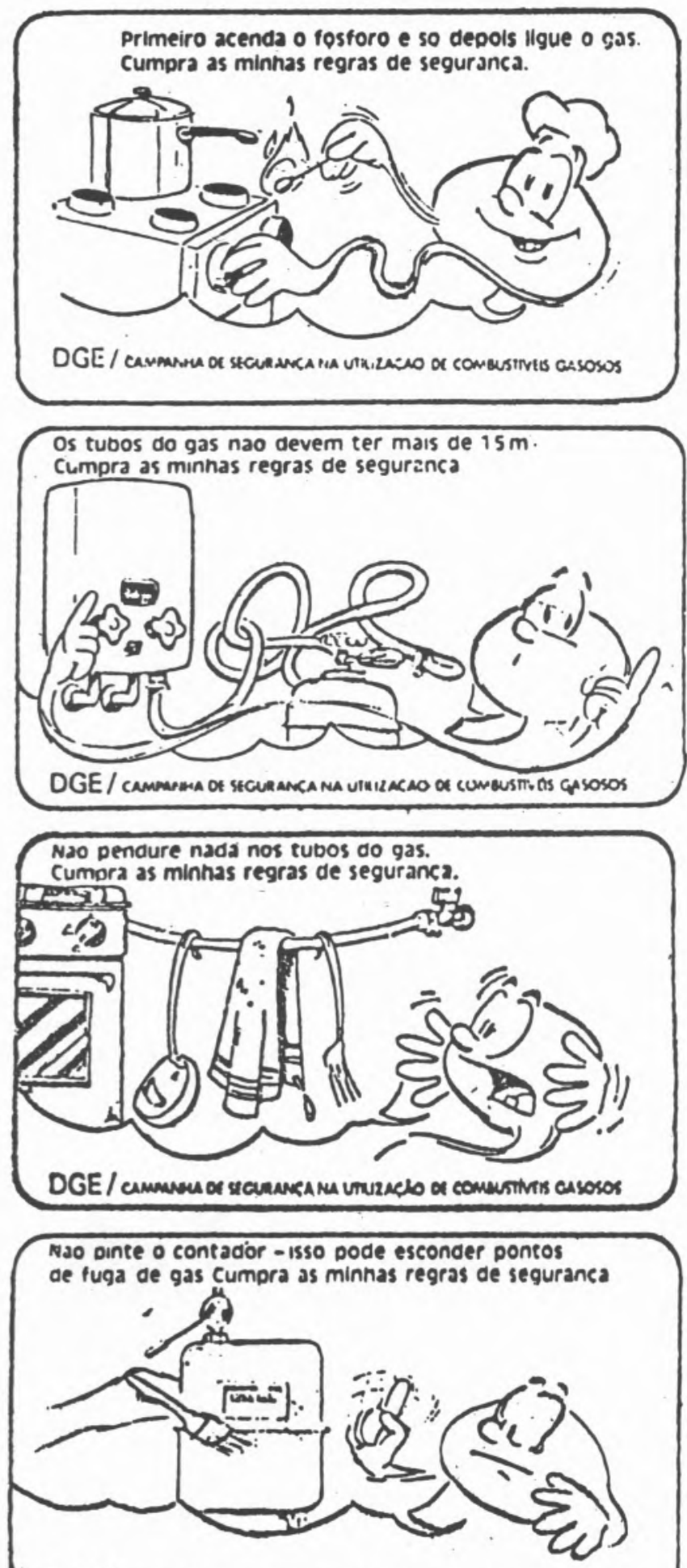

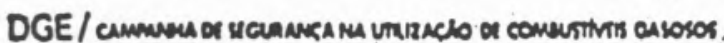

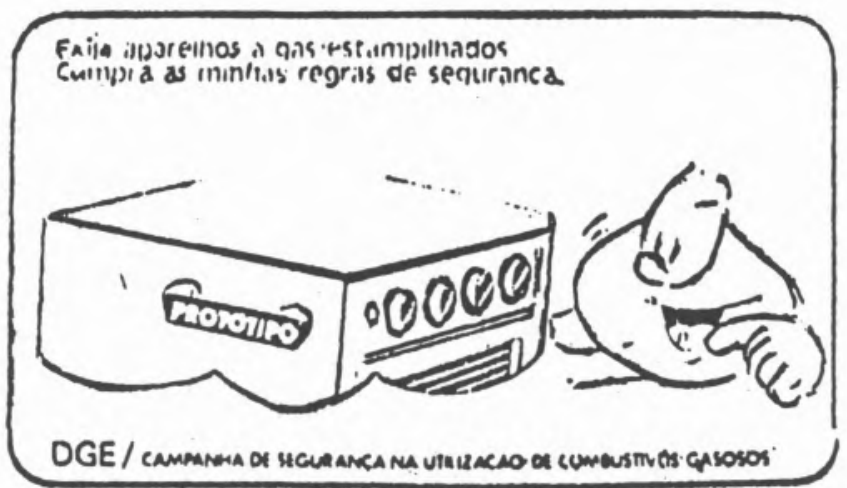

No final de Janeiro, ao ouvirem o último noticiário da TV, muitos cidadãos ficaram horrorizados com a notícia de uma explosão de gás na Escola de Cartaxo. Lembro-me das recomendaçðes de meus Pais "Não se brinca com o fogo". Vemos em muitas paragens de autocarros um belo cartaz com indicaçð̃es relativas ao uso de gás.

Algumas das aulas laboratoriais começam com uma iniciação aos cuidados a ter com o aquecimento, em especial com aquecimento a gás.

O facto consumado é que um acidente terrivelmente grave ocorreu numa escola. Desse acidente deve ter ficado para vários professores e alunos o alerta permanente para condiçð̋es básicas de segurança, quer na Escola, quer em casa.

Como estão os tubos e as torneiras de gás?

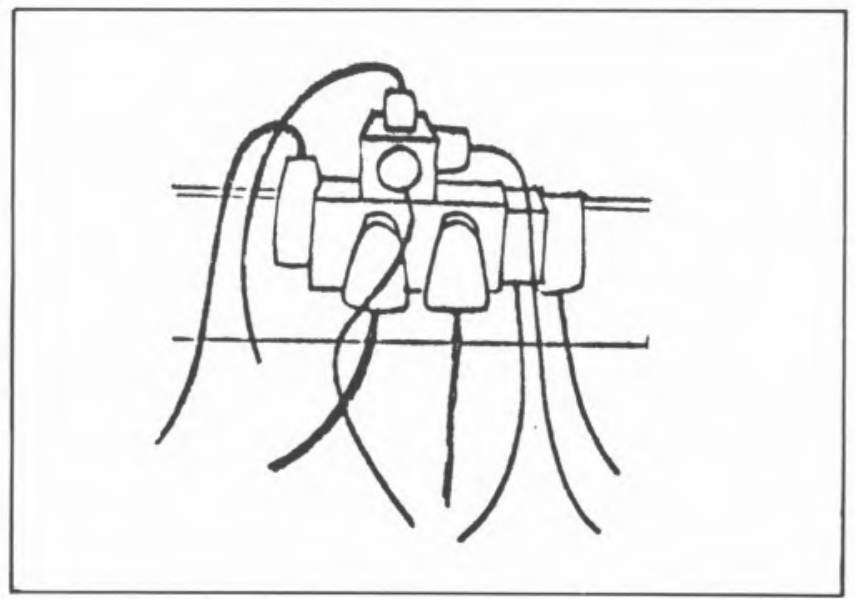

\footnotetext{
* Intervenção realizada no painel "Química para Químicos, Quími"ca para cidadãos" (8. ${ }^{\circ}$ Encontro Anual de Química, Universidade do Minho, Abril de 1985).

a Departamento de Educação, FCL.
} 
Como estão as tomadas de electricidade, as fichas, as fichas triplas, as ligações à terra?

Como proceder para que um fogo acidental não se propague?

Como tratar de queimaduras ligeiras que ocorreram com um objecto sólido ou com um líquido quente ou corrosivo?

As questð̃es sucedem-se.

Há cerca de dois meses num programa de televisão em que se pôs a questão "Diga nomes de elementos químicos", algumas das respostas foram dióxido de carbono, carbonato de cálcio, ácido sulfídrico, etc. Para nós, professores de Química, que logo nas primeiras aulas nos preocupamos a estabelecer com os alunos a distinção entre substâncias elementares e substâncias compostas, deve ter ficado a dúvida: a resposta dada por este cidadão será típica da resposta de outros cidadãos à mesma pergunta? Qual é a importância relativa que damos nas nossas aulas à distinção entre substâncias elementares e compostas e qual é a relevância que este tópico tem na formação em Química do cidadão?

E se a situação fosse outra?

No "Jornal" de 31 de Julho de 1981 apareceu em letras grandes
$\mathrm{Na}$ secção de armamento de "Science et Vie" (Outubro 1984) um artigo sobre a guerra bacteriológica classifica-a de 'horror total'. Mas o espanto é bem grande. ao ler que o Professor Ovchinnikov será o grande especialista da genética aplicada à guerra biológica: um químico de renome mundial usa a Química como meio de trabalho para a guerra, em vez de procurar um caminho para a melhoria da vida e para a Paz.

Em face dos holocaustos previsíveis, não é de admirar que haja preparativos para os combater (The Guardian, 3 Sept 1981);

No Vietnam foi utilizado durante a guerra o denominado agente laranja que provocou deformações tristemente célebres.

As afecções provocadas por metilisocianato em Bhopal e, as provocadas pela dioxina em Seveso, afligiram muitos cidadãos, alguns dos quais se manifestaram abertamente.

O caso de envenenamento na baía de Minamata é menos recente mas não menos preocupante. Durante 1953, os habitantes de Minamata, uma cidade altamen-

\section{Bomba de neutrões \\ Uma explosão na guerra}

\section{Chamam-lhe a "bomba limpa"...}

Primeire ouve-se, sente-se, o silve caracteristice da bomba a fender e ar. Depels, num instante, é e inapacte, o enorme charia e o estrondo. 0 calor, capaz de fundir instantaneamente o lerro, e e sopro brutal, arrasain entào tudo numa área variavel conforme a potêneia da
bomba. Depois, é o sllêncio entrecortado pelos gemidos bomba. Depols, é o sllênelo entrecortado pelos germidos assim que explode uma bomba convencional. Destrói e mata. A bomba de neutrö̀es também destrói, mas, sobretudo, mata. Depois da sua explosìo, o silêncio nunca poderia ser entrecortado pelos gemidos das vítimas. Mesmo vitimas. Mesmo lis longe, para alem do limite das ruinas, deinaria o siliemeio, mais com

Guerra, explosão, bomba, são termos conhecidos do cidadão; mas... neutrões, o que são? O impacto das consequências descritas no extenso artigo suplantam, para muitos cidadãos, as poucas linhas em que se explica o princípio da mesma. te industrial da ilha de Kyushu, no Sul do Japão, notaram que os gatos eram afectados por uma doença estranha: primeiro, andavam à roda mal se aguentando em pé, à medida que os músculos enfrequeciam; eventualmente ficavam paralisados e passavam por um es-

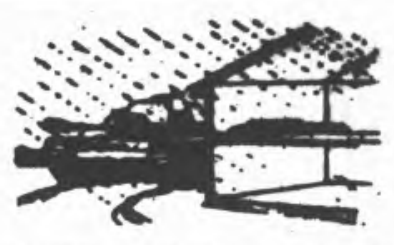

As radiacoles mortiferas penetram através das paredes das casas $e$, inclusivamente, das blindagens dos carros de combate

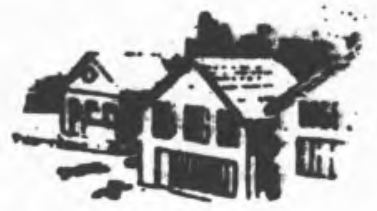

A explosito provoca poucos estragos nos edilicios e nas propriedades, permitindo o seu uso posterior

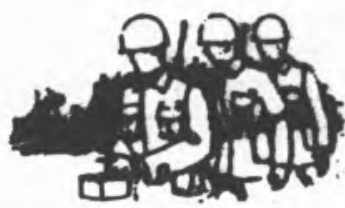

Liberta pouca radioactividade $e$ as suas radiapies năo alcançam grandes distâncias, o que permite a destocactio quase imediata de tropas para a zona bombardeada

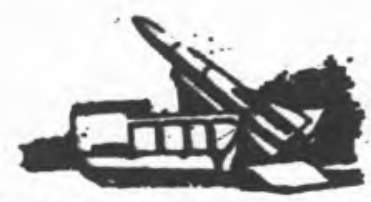

Pode disparar-se com a mesma precistio que um projectil de artilharia ou um missil. Portm, a morte por contaminacla neutromiónica pode ser lenta e dolorosa
No entanto, seria desejável que o leitor comum tivesse um espírito que lhe permitisse analisar a descrição feita do princípio da bomba, para melhor entender as consequências que ela provoca. tado de coma seguido de morte. Infelizmente as entidades sanitárias não entenderam os sintomas de envenenamento dos animais. Em Dezembro do mesmo ano foi relatado o primeiro caso desta doença numa pes- 


\section{Swiss survival food to beat holocaust}

from Ian Guest in Geneva

Switzerland's preparations against the nuclear holocaust were further refined yesterday
with the news that the huge with the news that the huge
multinational, Nestle, has de multinational, Nestle, has de-
veloped the world's first sur-
vival food-a glutinous, and by vival food-a glutinous, and by
all accounts foul-tasting substance which is intended solely
for use in the country's warren for use in the country's warren
of bomb shelters.

The first consignments of the new food will start rolling who is is needed for someone ccistrolled conditions and the the delivery main until the bombs start to person in a shelter by the fall. Nestle is preparing a Swiss Government's handbook rations, each of 50 grammes, There are two basic products. One, made of sugar, exclusity who lived on it shelter, and one of the biggest thole Swiss population for cocoa, cinammon, and vanilla, out any apparent sign of even contains a morgue and

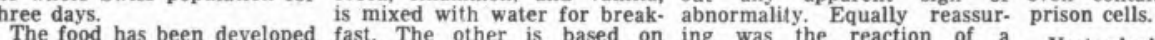

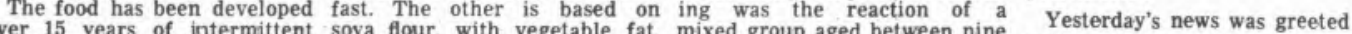
research. A Nestle spokesman yeast, and starch. It has the and 60 who were fed the sub. with derision by the Swiss explained yesterday that it is texture of porridge and (to stance over a period of three Association of Groups for

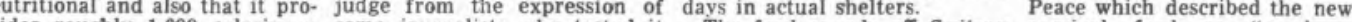
ides roughly 1,600 calories a some journalists who tested it The food rounds off Switzer- survival food as "a huge

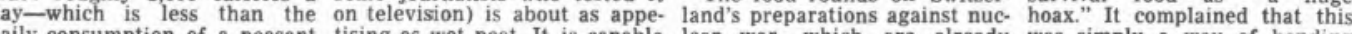
daily consumption of a peasant tising as wet peat. It is capable lear war, which are already was simply a way of handing
$n$ Bangladesh, but apparently of being stored for 10 years in among the most extensive in Nestlé a susidy of f10 milthe world - even though the lion, and suggested that the was in 1815. According to a better engaged in trying to Federal law, All new buildings a prevent engaged in trying to are required to have bomb cipate its horrors.

\section{Bhopal: India vai processar Estados Unidos}

O GOVERNO indiano vai processar judicialmente os Estados Unidos em nome das vitimas do desastre de Bhopal, em Dezémbro ủltimo, quando uma fuga de gás tóxico das instalaçôes da multinacional norte-americana Union Carbide naquela localidade indiana matou dois milhares e mejo de pessoas.

Por outro lado, vários advogados norte-americanos já apresentaram queixas contra a multinacional exigindo indemnizaçốes num montante de centenas de milhōes de dólàres.

soa; durante a década seguinte 43 pessoas morreram e mais de 60 ficaram permanentemente incapacitadas. A doença afectava também outros animais domésticos que se alimentavam de peixe; ao examinar peixe e moluscos da baía detectou-se que continha 20 a 60 vezes mais mercúrio do que aquele que normalmente se acumula no mar. Foi proibida toda a actividade piscatória na baía e iniciou-se a procura da fonte de mercúrio, tendo-se detectado que provinha de uma fábrica de cloreto de polivinilo, em que os efluentes da fábrica iam para a baía de Minamata.

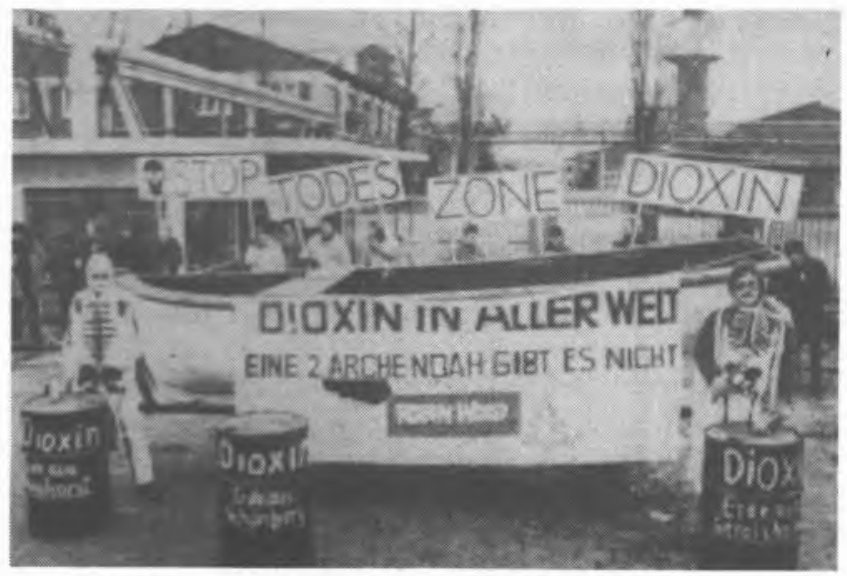

Manifestação em Hamburgo contra uma fábrica produtora de dioxina: os ecologistas capitalizam politicamente a irresponsabilidade do governo e das empresas oeste-alemãs

Embora nas experiências de laboratório se continue a utilizar mercúrio, os efeitos deste elemento e dos seus compostos não são referidos nos programas do ensino secundário.
Após o inverno particularmente frio que atravessámos este ano, o cidadão comum deve ter ouvido falar de vários combustíveis - petróleo, diesel, carvão, gás butano e gás propano - sem ter que considerar de

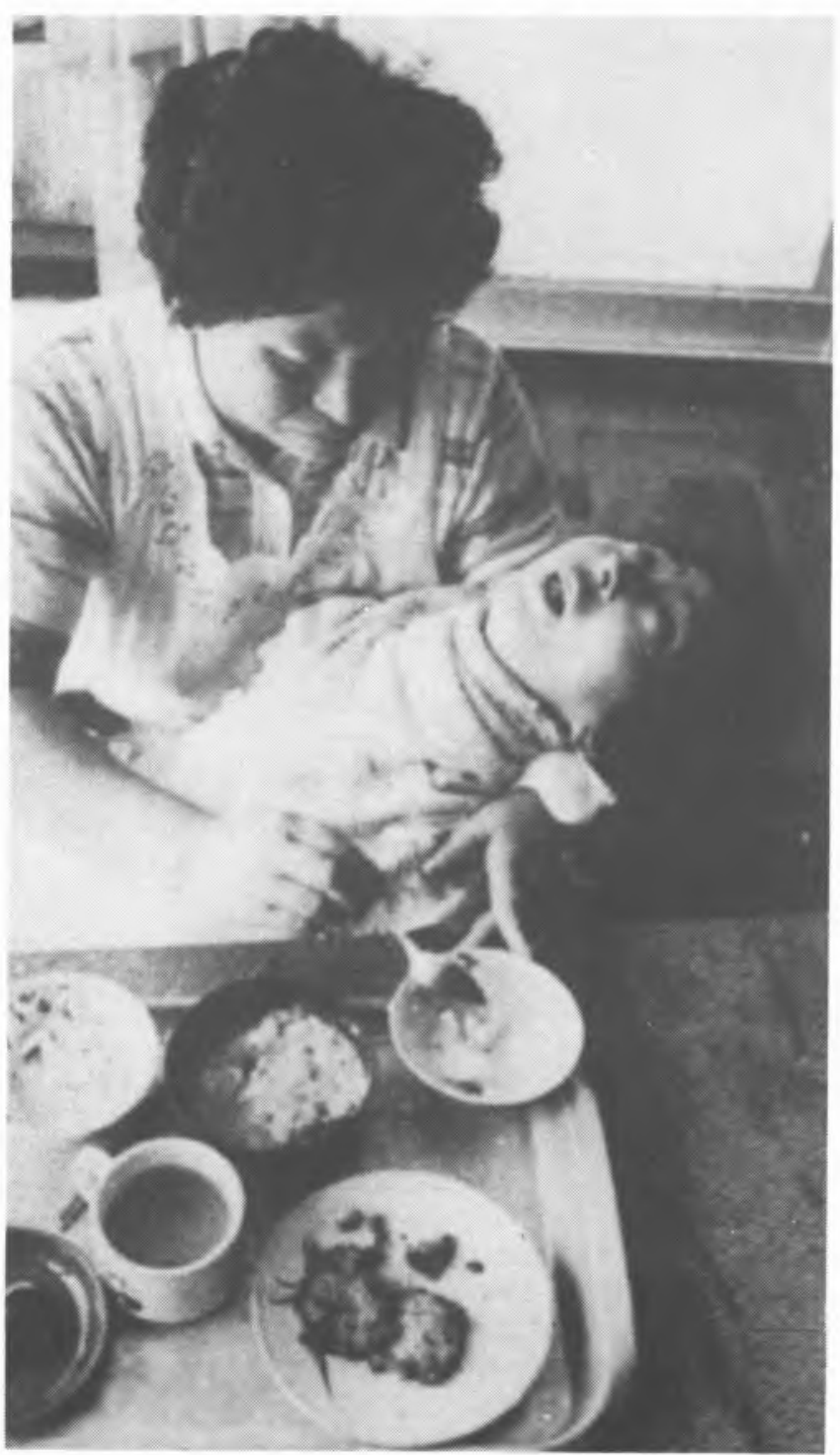

imediato, como característica predominante, o facto de serem substâncias poluentes. Aliás, existem minas de carvão limpas. 


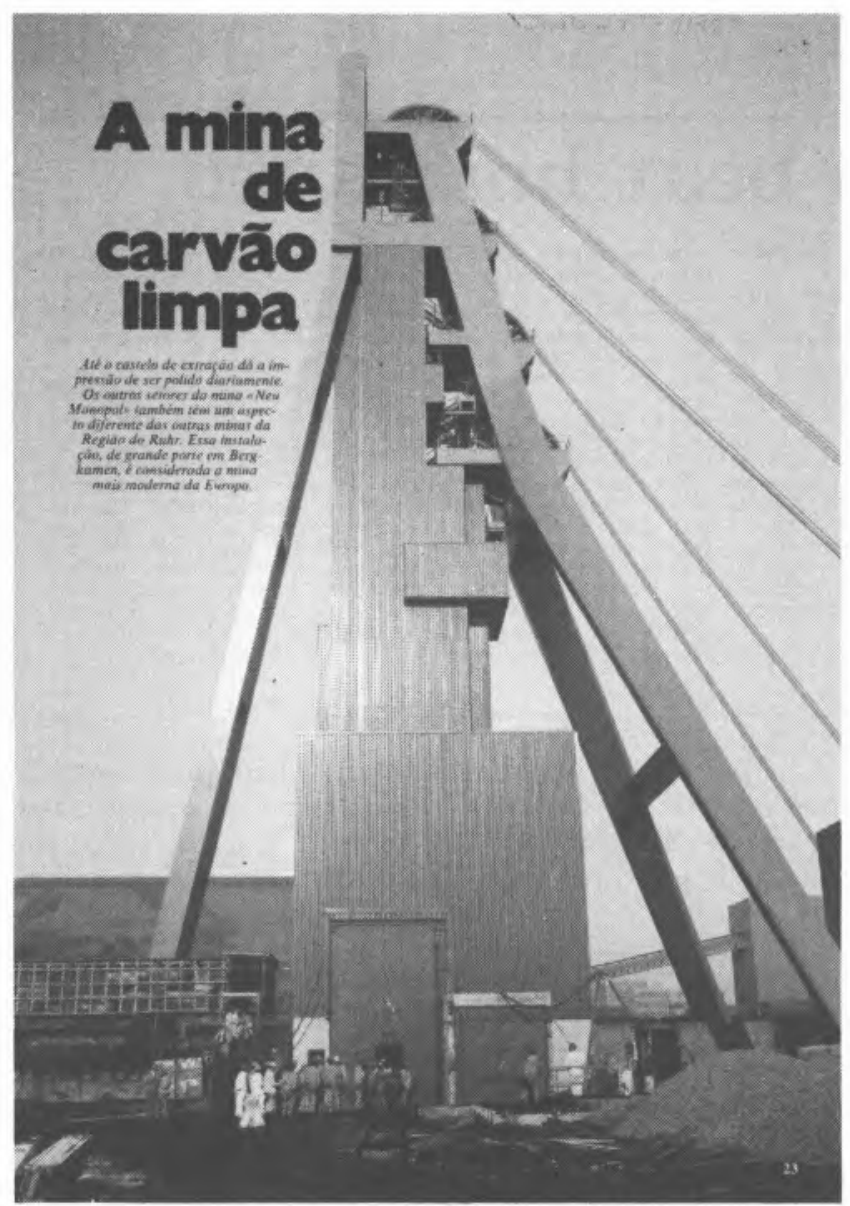

O crescente emprego dos motores térmicos, notavelmente em veículos, faz aumentar em muito a proporção de dióxido de carbono existente no ar. É importante que o cidadão comum saiba que amostras de ar recolhidas em vários locais - montanha, campo, ci-

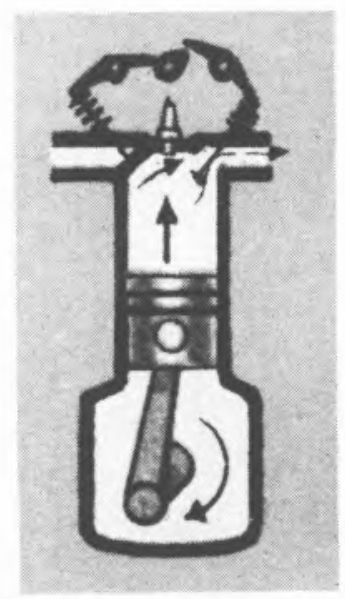

dade - e a várias horas do dia, contêm diferentes números de bactérias, bem como de outros constituintes. Nas cidades onde há grande densidade populacional, o ar quente é carregado de gases nocivos e de micróbios.

O fumo e os gases contaminam o ar provocando muitas doenças e agravando uma série de outras. Um dos focos da poluição é o tubo de escape dos automóveis, donde se desprende muito monóxido de carbono. Assim, muitas cidades do Mundo executam planos de

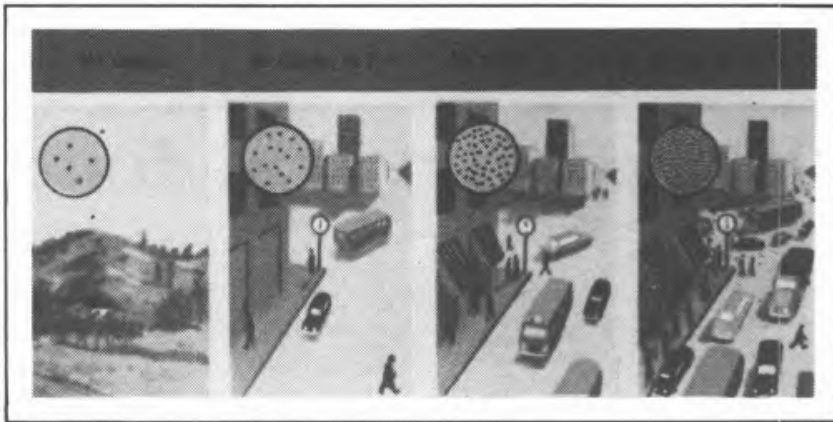

controlo da poluição do ar e é importante que o cidadão os conheça. Uma das providências tomadas tem sido preparar gasolina sem chumbo, que protege igualmente o motor do automóvel.

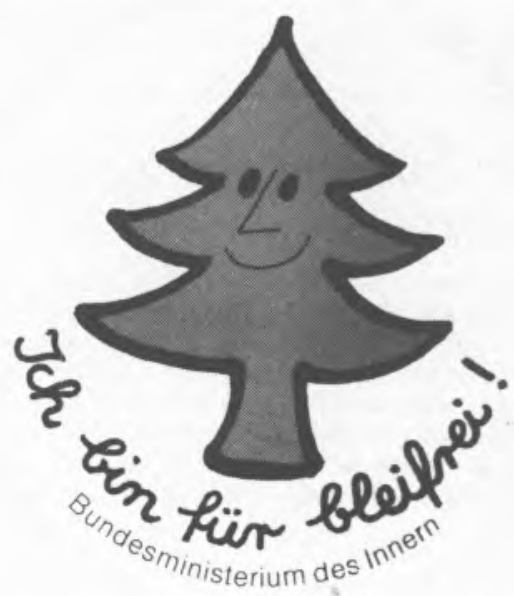

Um outro aspecto da relevância da Química para o cidadão é o estudo de processos de conservação de alimentos. Um artigo refere que

\section{Conservantes de alimentos preocupam americanos}

É dada a informação da percentagem de pessoas que apresentam sensibilidade aos sulfitos e de alimentos que podem conter sulfitos. Além disso refere-se que os sulfitos têm uma função essencialmente estética, isto é, empregam-se para dar aos alimentos um aspecto fresco. A 'Food and Drug Administration' (E. U. A. N.) está a elaborar novas regras para a etiquetagem que obrigará a especificar os níveis a partir dos quais os sulfitos terão de ser identificados nas embalagens de alimentos.

Qualquer cidadão comum sabe que uma das utilidades do frigorífico é permitir que os alimentos não se deteriorem. No curso secundário o aluno estuda que um aumento de temperatura aumenta a velocidade de reacções químicas e sabe que, inversamente, o frio é importante na conservação de alimentos.

Em 1798, exploradores na Sibéria setentrional, famintos e mal protegidos para o frio intenso, abrigavam-se na tenda. De repente, o latido dos cães levou-os ao ar livre. Os animais exaltados cavavam furiosamente, até que apareceu o corpo enorme de um mamute congelado, do qual cozinharam e comeram um bife de milhares de anos, perfeitamente conservado. Após 


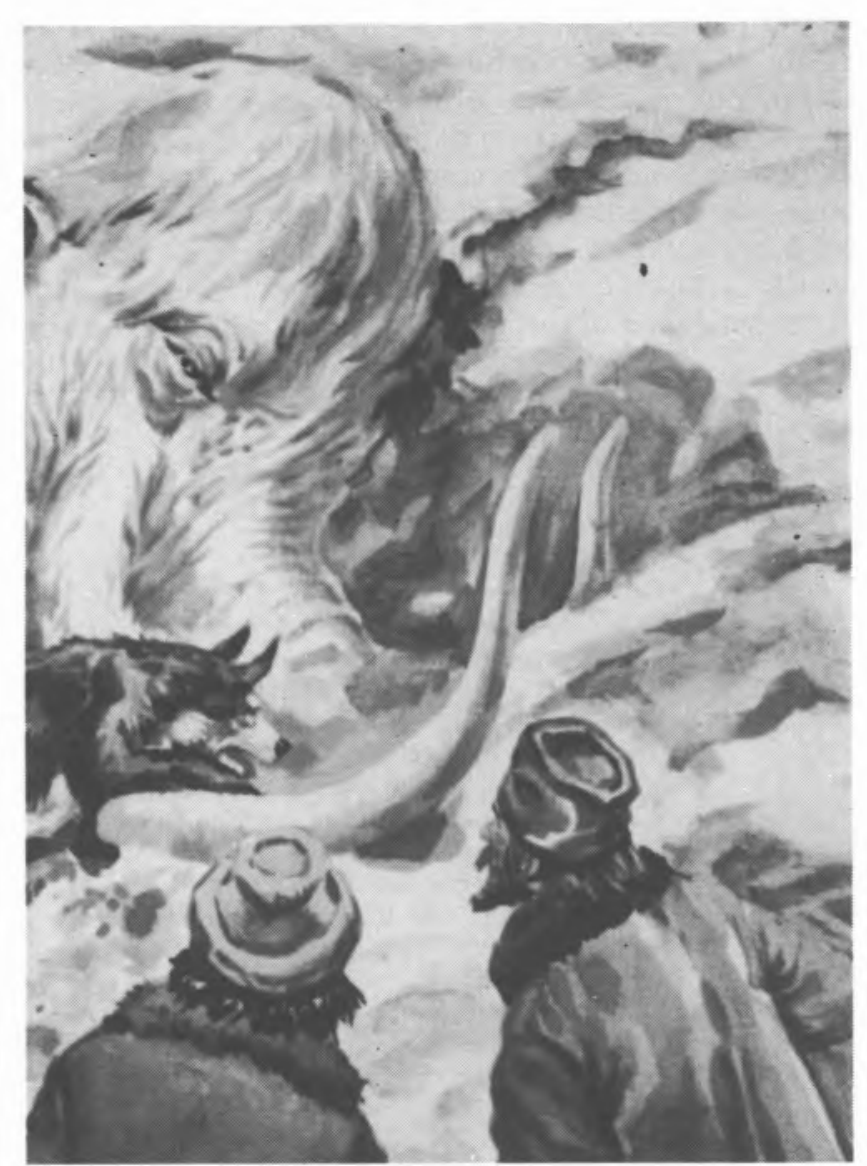

esta cena real, os homens têm constantemente explorado vários métodos de refrigeração, num dos quais se utiliza 'gelo seco', que em 1923 já era utilizado nos Estados Unidos da América do Norte, para fins industriais. É importante que o cidadãos saiba que o gelo seco não é gelo no sentido comum do termo; este, não funde, sublima a $-78^{\circ} \mathrm{C}$, não deixa resíduos nem humidade e, pode ser tocado por pouco tempo sem perigo, porque o produto que sublima, por ser mau condutor do calor, forma uma camada isolante entre a substância e a pele. O gelo seco é importante para a conservação dos alimentos porque, para além das características referidas anteriormente, tem propriedade antisépticas, que ajudam a conservar os alimentos.

Haverá outras preocupações que a Química levante ao cidadão?

Noutro artigo (de “'A Capital”), pretende-se alertar os consumidores para o uso de dezodorizantes nas casas de banho. Os desodorizantes de sanita que foram

\section{CONSUMIDOR PREVENIDO}

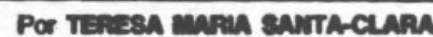

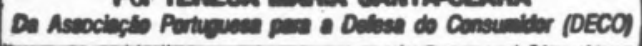

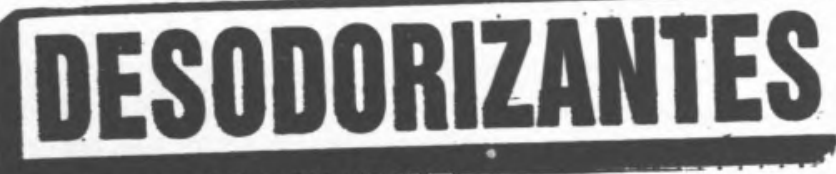

analisados, além de não eliminarem os cheiros nem dispensarem uma boa lavagem da sanita, não são suficientemente desinfectantes e a substância que os constitui é dificilmente biodegradável sendo, pois, inconvenientes para o ambiente.

A poluição de origem química nos monumentos e florestas afectadas pelas chuvas ácidas parece estar a acelerar o devastamento ecológico.

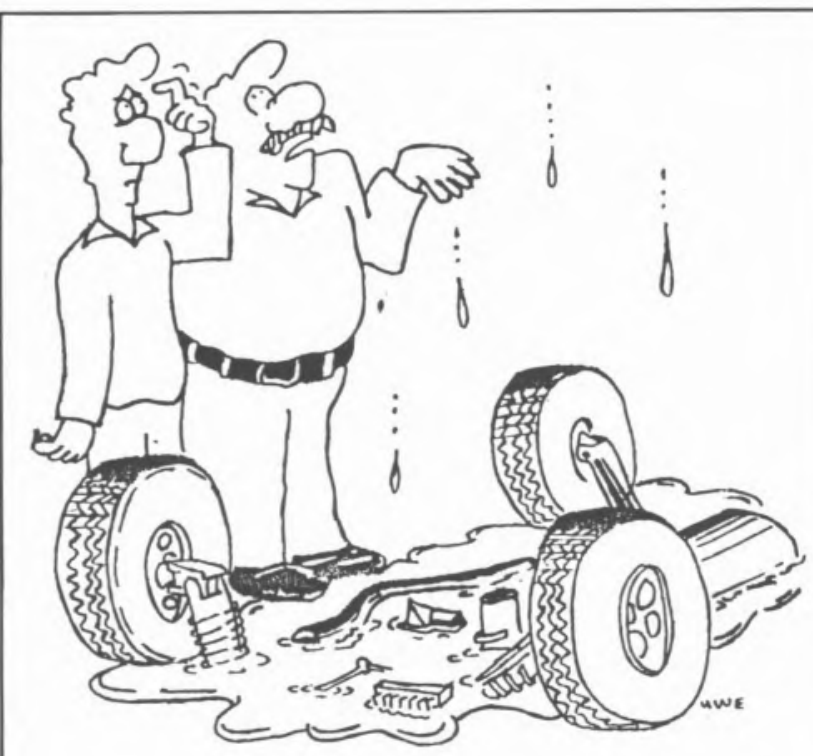

ACID RAIN AND OTHER INTERNATIONAL PROBLEMS: HOW TO ASSESS THE RISK, AND WHAT SHOULD BE DONE
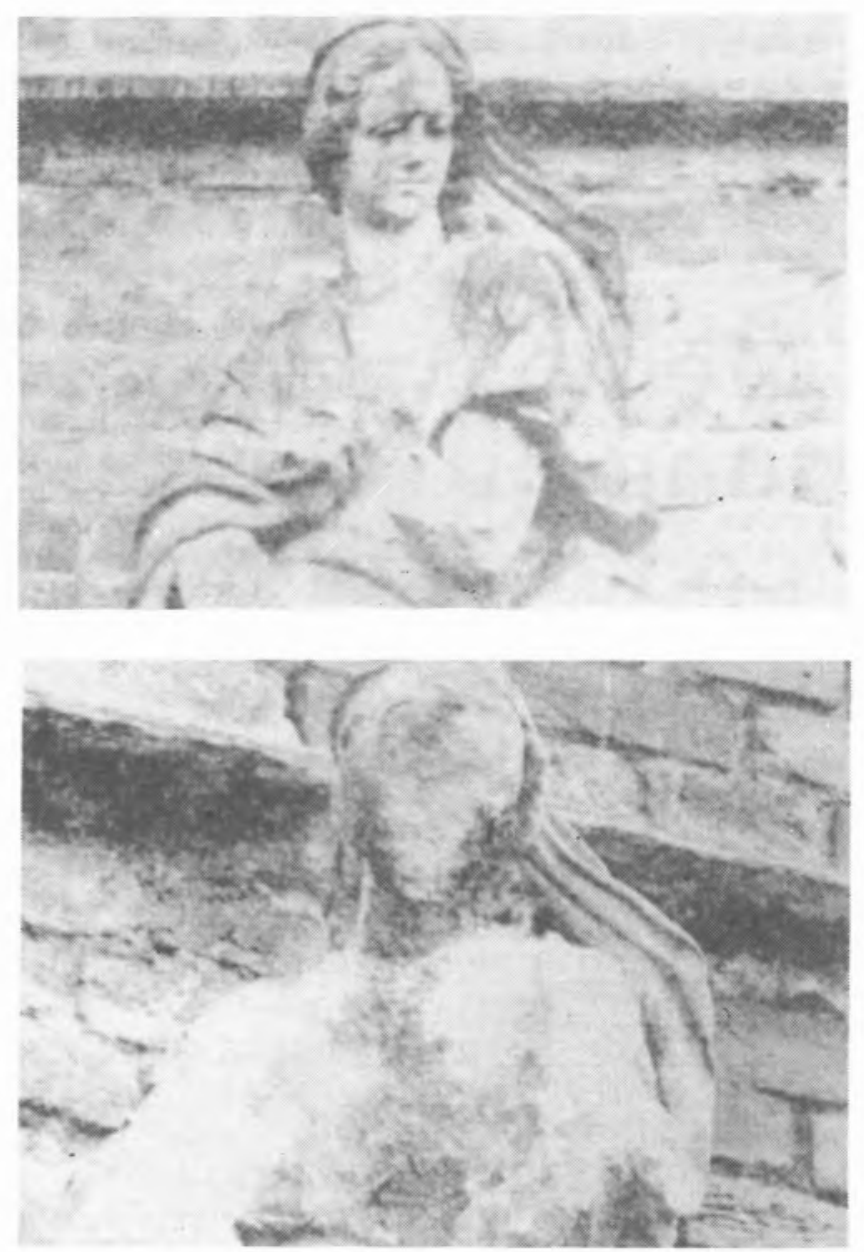
Para que possamos respirar a poeira atmosférica é purificada, isto é, é preciso que perca as substâncias e os microorganismos que são prejudiciais à saúde do corpo. É necessário que o cidadão saiba que a primeira defesa contra aquelas impurezas está nas narinas, onde os pêlos aí existentes retêm a poeira, purificam e humedecem o ar, sendo o calor proporcionado pelos vasos sanguíneos e a humidade proveniente das glândulas lacrimais.
O petróleo que polui a água e o 'smog' que atormenta os olhos, são produtos químicos. Todo o nosso corpo, por assim dizer, é um laboratório de Química.

A Química faz parte da nossa cultura, da nossa vida quotidiana. Os medicamentos, os polímeros, as pinturas, os produtos farmacêuticos têm todos alguma coisa em comum: uma estrutura química.

A Química é uma ciência viva que representa uma parte activa da investigação que ajuda a resolver os

\section{BONS ARES DÃO SAUUDE MELHOR}

Suspensas no ar, exis$S$ tem de modo geral inúmeras partículas formando o que se chama poeira atmosférica. Para que a gente possa respirar, é necessário que êsse ar fique purificado ou seja, perca as substâncias e os microrganismos que são tão prejudiciais à saúde do corpo humanu.

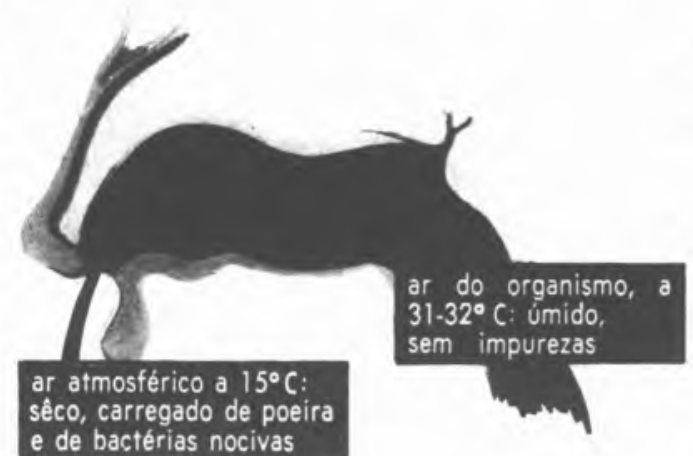

A primeira defesa do organismo contra aquelas impurezas está nas narinas. As vibrissas (os pêlos ali existentes) retêm a poeira suspensa no ar. Nas narinas, o ar é ainda aquecido e umedecido. Esse trabalho se realiza na mucosa que recobre as fossas nasais: o calor é proporcionado pelos vasos sangüíneos que ali circulam; a umidade provém da secreção que chega das glândulas lacrimais. Assim tratado, o ar que vai aos pulmōes nāo pode causar danos: está filtrado, esterilizado, com o calor e a umidade necessários. Quando respiramos pela bôca o ar chega impuro aos pulmôes, ameaçando nossa saúde.
É evidente que não se pode ignorar a Química porque ela não nos ignora. A exposição de posters "A Química a seu lado" em exibição no sector de Educação do Encontro de Química de 1984 ilustroú convenientemente que na nossa sociedade estamos rodeados de produtos químicos. O vestuário que se usa, os alimentos que se comem são produtos químicos. As aspirinas e outros medicamentos são produtos químicos; alguns, não convenientemente testados, podem ter consequências desastrosas.

\section{saúde \\ Medicamentos: uma pílula pode esconder a morte}

Todo o Terceiro Mundo. é o palco preferido das drogas de acção duvidosa, distribuidas pelas multinacionais. $E$ até nos países em via de desenvolvimento, como é o caso de Portugal, as centrais mundiais dos remédios chegam a controlar $80 \%$ dos mercados. problemas actuais. As reacções químicas produzem-se continuamente à nossa volta e é necessário compreender os problemas quotidianos que nós enfrentamos e aqueles com que o nosso ambiente se debate. Devemos ter como meta que os alunos desenvolvam a curiosidade, ponham questões, discutam os problemas quotidianos e tenham referências temporais relativamente às descobertas e produtos criados pelos químicos. Mas, acima de tudo, tomem conhecimento dos compostos do nosso universo e da importância da sua vivência nesse universo, de modo a que seja melhor e mais feliz.

A Química é muitas vezes descrita como uma ciência experimental que trata da transformação dos elementos e das suas propriedades. A Química, tal como os químicos a vivem, ajuda-nos a compreender o Mundo em toda a sua complexidade desenvolvendo uma estrutura lógica de raciocínio e um método de trabalho sólido, utensílios indispensáveis neste mundo altamente científico e tecnológico.

A Química, estudada num contexto cultural, social e económico ajudará grandemente e servirá de ferramenta útil em qualquer estudo de ciências.

Será que aqueles alunos que não têm intenção de seguir uma carreira de Química a vêem como qualquer coisa que só diz respeito aos químicos? Ou, pelo contrário, será que esperam impacientemente pelo dia em que o professor os leva a trabalhar no laboratório da escola? Qual é a reacção final dos alunos a quem durante dois anos do curso unificado não lhes foi dada a possibilidade de experimentarem um pouco do trabalho dos químicos nem lhes foi mostrado que a Química faz parte da vida deles, que vivem no final do século $\mathrm{XX}$ ?

Espera-se que um aluno que não segue uma carreira de Química seja um simples espectador? Ou espera-se que ele desenvolva ideias pessoais?

Pretende-se que um aluno ignore os problemas que ameaçam a sociedade de hoje? Ou pretende-se que 
o aluno fique com capacidades desenvolvidas para resolver estes problemas?

Podemos controlar a crise energética, e a que preço?

A nossas necessidades de energia e o nosso desejo de um meio de qualidade são compatíveis? Como é que os problemas de energia e do meio ambiente afectam a nossa vida?

Como cidadãos compete-nos examinar esta espécie de problemas. Quanto melhor forem reconhecidos estes problemas, mais inteligente será a resposta. Nos nossos dias é útil conhecer os produtos sintéticos e os aditivos, os fosfatos e os glúcidos, bem como o seu uso.

Somos capazes de impedir o ferro (das carrocerrias dos automóveis, por exemplo) de enferrujar?

Somos capazes de produzir um remédio que trate o cancro? Um remédio que trate a depressão?

Somos capazes de preparar combustíveis que não sejam poluentes?

Apesar de aspectos negativos aqui mencionados, está nas mãos dos cidadãos o controlo dos acontecimentos. É da responsabilidade dos professores de Química referir aos alunos que estão rodeados de fenómenos químicos. É certo que há causas químicas que originam perturbaçð̃es nefastas. Mas há estudos conducentes a que se neutralizem essas reaç̧̃es; esses estudos são postos em execução quando há vontade política e vontade da direcção das empresas para o fazer.

O universo existe há vários milhares de anos. A vida do Homem na Terra existe há alguns milhares de anos e, a vida do Homem veio acompanhada de um livro em branco sem indicaçð̃es do que se deveria e do que não se deveria fazer.

A vida de cada um de nós é um curto intervalo de tempo comparado com o tempo de existência do universo e, corresponde a uma página do livro no qual escrevemos a história do Homem na Terra. É a cada um de nós, químicos e não químicos, que compete a responsabilidade do que se escrever na página do livro, correspondente à sua curta passagem pela Terra.

Haverá esperança para o cidadão de hoje e para o de amanhã? Está nas mãos dos cidadãos o controlo dos acontecimentos.

\section{Bibliografia}

Araújo, R. \& Capinha, A. (16 de Outubro de 1982). Medicamentos: uma pilula pode esconder a morte. Expresso, 18R-19R.

Bomba de neutrões - uma explosão na guerra das superpotências. (31 de Julho de 1981). O Jornal, 21-21.
Bons ares dão melhor saúde (1967). Conhecer, 2(29), 480-481.

Brody, J. (26 de Dezembro de 1984). Conservantes de alimentos preocupam americamos. Diário de Notícias. 31-33.

Callagan, J., Garrod, A. \& Godwin, J. [1979]. Oil pollution. R S P C A .

Castro, P. V. (7 de Julho de 1984). Poluição, a catástrofe ecológica. O Jornal, 43R-50R.

Chemistry all around us. (July 1982). Report of a seminar. Norwich: University of East Anglia.

Chemistry films at the 1985 Meeting of The Association for Science Education.

Direcção Geral de Energia (s/d). Campanha de segurança na utilização de combustiveis gasosọs.

Gardner, M. (1980) in Huheyey, J. Diversité et Periodicité. Montréal: Études Vivantes

Garforth, F. (July 1982). International seminar on Chemical Education. Norwich: University of East Anglia.

Gelo seco (1967). Conhecer, 3 (34), 576-577.

Gervais, R. (1980). in Huheyey, J. Diversité et Periodicité. Montréal: Études Vivantes.

Guest, I. (5 September 1981). Swiss survival food to beat holocaust. The Guardian.

Hill, G. \& Holman, J. (1978). Chemistry in context. Surbury-on-Thames: Nelson.

IUPAC (1981). Chemistry International, 1, 3-5.

McKnight, D. \& Coldam, M. (1975). Chemistry in context. London: Hutchinson Educational.

A mina de carvão limpa (s/d). 23-26.

Motores a combustão (1976). Conhecer. 2 (17), 278-281.

O óleo de pedra (1976). Conhecer. 2 (17) 278-281.

Ortoli, S. (Octobre 1984). Le quatrième cavalier de l'Apocalipse. Science et Vie, 84-91, 166-168, 170, 172, 174, 176-177.

Parker, S., ed. (1980). Encyclopedia of environmental Science. New York: McGraw Hill.

Perina, I. (1982). Popularization of chemistry through ecological topics. Journal of Chemical Education, 59, 1016-1017.

Santa-Clara, T. (s/d). Consumidor prevenido-desodorizantes. $A$ Capital.

Scientists play a leading role in forming high-technology industries. (1982). Chemistry International. 4, 1-2.

Vitz, E. (1979). The ambit of chemistry. Journal of Chemical Education, 56, 327-328. 